\title{
PENGARUH PEMBELAJARAN DARING DI MASA PANDEMI TERHADAP PERKEMBANGAN SOSIAL ANAK KELAS 6 SD
}

\author{
Salsha Fairuz Putri Isa, Triana Lestari \\ Universitas Pendidikan Indonesia Kampus Daerah Cibiru \\ Email: salshafairuz@upi.edu, trianalestari@upi.edu
}

\begin{abstract}
Abstrak
Perkembangan sosial adalah pencapaian kematangan dalam hubungan sosial. Penelitian ini bertujuan untuk mengetahui bagaimana pengaruh atau dampak pembelajaran daring di masa pandemi terhadap perkembangan sosial anak kelas 6 SD. Metode yang digunakan dalam penelitian ini yaitu kualitatif-deskriptif. Teknik pengumpulan data yang digunakan dan dilakukan oleh peneliti dalam penelitian ini adalah wawancara dan data dianalisis menggunakan tematik. Pembatasan interaksi sosial selama pandemi telah membatasi ruang sosial anak-anak, dan mereka tidak dapat meninggalkan rumah, serta bermain bebas dengan teman sebayanya. Pembatasan interaksi sosial anak akan memengaruhi perkembangan sosial anak. Perkembangan sosial yaitu hasil dari hubungan sosial yang matang, juga dapat dipahami sebagai proses pembelajaran norma, etika, dan tradisi, yaitu menyatukan diri menjadi satu kesatuan yang saling tukar menukar dan bekerjasama. Hal tersebut akan berdampak pada keadaan psikologis anak, membuatnya tidak terbiasa dengan lingkungan sosialnya di kemudian hari dan tidak mau berinteraksi dengan orang lain. Perkembangan sosial seorang anak akan memberi pengaruh terhadap cara anak bersosialisasi dengan lungkungannya serta manfaat yang dapat dihasilkan dari sosialisasi tersebut. Pembelajaran daring di masa pandemi memberikan pengaruh terhadap perkembangan sosial anak jenjang sekolah dasar khususnya kelas 6 SD. Hasil dari penelitian yanng telah dilakukan memberi gambaran yakni pembelajaran daring berpengaruh bagi perkembangan sosial seorang anak.
\end{abstract}

Kata Kunci: Perkembangan Sosial Anak, Pembelajaran Daring, Masa Pandemi, Sekolah Dasar.

\section{PENDAHULUAN}

eluruh dunia dan tak terkecuali Negara Indonesia sedang menghadapi

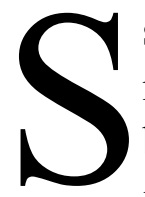
situasi dimana virus merebak dan menjangkit banyak orang, mengakibatkan banyak kerugian dalam bidang politik, ekonomi, sosial, budaya, dan tak terkecuali dalam bidang pendidikan. Ditemukannya virus ini untuk pertama kalinya di Wuhan, China dan dinamai dengan Covid19. Virus ini masuk ke Indonesia pada Bulan Maret tahun 2020. Pemerintah melakukan segala cara untuk menanggulangi virus ini dimulai dengan anjuran protokol kesehatan yang harus masyarakat taati dan pemberlakuan Pembatasan Sosial Berskala Besar atau PSBB. Semua kegiatan dimulai dari perdagangan, pekerjaan, pembelajaran, dan lainnya diupayakan dilakukan di 
rumah dengan maksud untuk mengurangi hubungan secara langsung antar individu dengan harapan cara ini dapat mengurangi penyebaran virus Covid-19. Pemerintah Indonesia mengimbau kepada masyarakat untuk menerapkan jaga jarak serta jaga kontak fisik. Pemerintah di Indonesia telah berusaha dengan berbagai cara, antara lain: (1) Isolasi mandiri bagi warganya yang diduga terinfeksi COVID-19, (2) Menjaga jarak antarmanusia, (3) Membatasi perjalanan dalam negeri maupun luar negeri, (4) Melarang adnya kumpulan atau kerumunan, (5) Penutupan toko, restoran, tempat umum, hingga sekolah (C.-A. Indonesia \& Indonesia, 2020) dilakukan dengan sistem jarak jauh atau dari rumah masingmasing sesuai imbauan Presiden Joko Widodo (Dewayani, 2020).

Dengan munculnya virus, ada tantangan tersendiri bagi semua manusia di dunia serta menjadi ancaman untuk kesehatan dari manusianya itu sendiri. Covid19 memberikan dampak yang signifikan terhadap pelaksanaan tatanan kehidupan dan tentunya dalam sistem pendidikan yang dampaknya dapat kita rasakan sampai saat ini. Karena tingginya pandemi, universitas dan perguruan tinggi di seluruh dunia ditutup (Fredy et al., 2020) juga berlaku hingga tingkat sekolah dasar. Berdasarkan surat yang diedarkan oleh pemerintah pada tanggal 18 Maret tahun 2020, seluruh kegiatan baik yang dilakukan dalam ruangan maupun luar ruangan ditunda untuk sementara waktu untuk mengurangi kluster masyarakat yang terpapar virus Covid-19. Mendikbud mengedarkan Surat Edaran No. 4 Tahun 2020 tentang Pelaksanaan Kebijakan Pendidikan dalam Masa Darurat Covid-19. Dengan adanya kebijakan yang dikeluarkan pemerintah, diharapkan masyarakat dapat melakukan segala aktivitasnya dari rumah dan tetap mematuhi protokol kesehatan yang dianjurkan. Salah satu peraturan pemerintah adalah melakukan isolasi mandiri atau tidak bepergian kecuali diperlukan. Namun jika semua aktivitas hanya dilakukan di rumah maka akan menimbulkan efek psikosomatis yaitu gangguan fisik yang diakibatkan akumulasi emosional dan faktor psikologis yang akan berdampak pada seseorang di masyarakat, seperti kecemasan, stres, lingkungan yang memberikan dampak negtif bagi pikiran. (Fadlila, 2020).

Perkembangan awal anak dipengaruhi oleh berbagai latar belakang sosial dan budaya, termasuk keluarga, pendidikan, masyarakat dan masyarakat secara keseluruhan. Perkembangan banyak mencerminkan pengaruh dari keluarga dan sistem mikro yaitu lingkungan hidup. Konteks ini meliputi keluarga, teman sebaya, sekolah, dan lingkungan sekitar.Interaksi paling langsung terjadi dalam sistem mikro dengan orang-orang sosial, seperti interaksi dengan orang tua, guru, dan teman sebaya. Anak-anak yang langsung bersekolah juga jauh lebih matang secara sosial dan emosional. Hal ini dikarenakan ketika anak belajar di sekolah, anak sering berinteraksi langsung dengan guru dan temannya untuk merangsang perkembangan sosial dan emosionalnya (McDonald et al., 2018). 
Saat ini, pembelajaran online diharuskan karena kondisi pandemi yang mengharuskan sekolah ditutup sementara. Namun disisi lain pembelajaran online memiliki dampak pada perilaku sosial anak. Hal ini disebabkan oleh banyak faktor, diantaranya anak jarang bermain dan bersosialisasi dengan teman sebayanya, anak merasa bosan dan sedih karena selalu berada dalam rumah, serta anak rindu kepada teman-teman sekolahnya dan juga guru-gurunya.

Penelitian mengenai perkembangan sosial anak sekolah dasar dengan berbagai penyebabnya sudah banyak dianalisis oleh peneliti-peneliti terlebih dahulu. Namun, perkembangan sosial bagi anak sekolah dasar yang melaksanakan pembelajaran jarak jauh di masa pandemi saat ini belum banyak dilakukan oleh peneliti-peneliti. Penelitian ini memiliki tujuan untuk mengetahui bagaimana pengaruh pembelajaran daring terhadap perkembangan sosial anak sekolah dasar khususnya anak kelas 6 SD.

\section{METODE PENELITIAN}

Metode yang peneliti gunakan pada penelitian ini yaitu kualitatifdeskriptif, menganalisis bagaimana pembelajaran daring di masa pandemi saat ini memengaruhi perkembangan sosial anak kelas 6 SD. Subjek dalam penelitian ini adalah siswi kelas 6 SD berinisial STH, latar belakang dipilihnya STH sebagai subjek karena pertimbangan lokasi peneliti yang berada dekat dengan tempat tinggal subjek sehingga akan memudahkan peneliti untuk mengumpulkan data. Teknik pengumpulan data yang digunakan peneliti adalah wawancara dan analisis tematik (menekankan penyusunan koding atas pertanyaan penelitian yang telah ditetapkan, tema disusun sesuai dengan pertanyaan penelitian dan menjadi acuan untuk menjelaskan apa yang terjadi (Heriyanto, 2018).

\section{HASIL DAN PEMBAHASAN}

Sesuai Surat Edaran Nomor 4 Tahun 2020 tentang Pelaksanaan Kebijakan Pendidikan Selama Masa Darurat Penularan Covid, direkomendasikan agar semua proses pembelajaran dilakukan secara daring atau tatap maya di bawah kerjasama guru, siswa, dan orang tua dari keluarga anak. Pembelajaran daring mempengaruhi perkembangan sosial anak. Dampak sosial dan emosional pembelajaran online pada anak antara lain anak menjadi bosan karena sering berada di rumah, kehilangan interaksi dengan teman dan tercacat juga beberapa anak mengalami kekerasan verbal yang disebabkan oleh proses pembelajaran yang lazim (Antara dan Prima, 2020).

Dari wawancara yang telah dilakukan peneliti kepada salah satu siswa kelas 6 SD berinisial STH, sosialisasi antara anak dan juga teman-teman serta gurunya menjadi kurang karena anjuran protokol kesehatan dari pemerintah guna memutus rantai penyebaran Covid-19. Hal itu memang baik dilakukan agar kita 
terhindar dari virus ini, namun memberikan dampak bagi perkembangan sosial anak karena menjadikan anak kurang berinteraksi sosial dan bergaul namun hal ini pun membuat anak dapat menyesuaikan diri dengan keadaan di lingkungan sekitarnya. STH mengungkapkan bahwa di masa pandemi ini ia berkomunikasi dan berinteraksi dengan teman sekelasnya dan juga guru-guru hanya melalui aplikasi WhatsApp.

Selain itu, STH mengungkapkan dengan adanya pembelajaran daring ini motivasi belajar yang ia miliki menurun. Hal ini disebabkan oleh dengan pelaksanaan pembelajaran daring, guru hanya memberikan materi dan menugaskan latihan-latihan soal yang harus dikerjakan siswa. Guru hanya menjelaskan kepada siswa dua kali dalam seminggu menggunakan aplikasi pendukung seperti Zoon Meeting ataupun Google Meet. Bahkan, guru terkadang hanya memberikan latihan soal yang harus dikerjakan oleh siswa tanpa memberikan materi dan mengharuskan anak untuk mencari materi secara mandiri ataupun dibantu oleh orang tua serta keluarga yang ada dalam keluarga. Namun sesekali, tidak semua siswa dapat memahami apa yang ia cari melalui internet karena siswa tetap membutuhkan penjelasan dari gurunya terkait pembelajaran yang disampaikan.

Dengan adanya pembelajaran daring, siswa terkadang merasa bosan dan jenuh. Rasa bosan ini ditimbulkan karena kondisi lingkungan anak yang monoton dan kurang menarik. Hal ini juga menyebabkan anak terkadang malas untuk belajar. Disisi lain, dengan adanya pembelajaran daring ini anak pun memiliki waktu luang lebih banyak bersama orang tuanya. Anak yang biasanya ketika pulang sekolah langsung istirahat dan mengerjakan tugas rumahnya kini memiliki waktu yang dapat dikatakan lebih banyak tinggal dan diam di rumah serta berinteraksi dengan orang tuanya dirumah.

Ketika pembelajaran dilakukan di rumah, tentunya peran orang tua menjadi lebih besar dibandingkan sebelumnya. Jika sebelumnya beberapa orang tua menyerahkan urusan pendidikan anaknya ke sekolah masing-masing kini mau tidak mau harus ikut dalam pembelajaran. Hal ini menjadikan anak pun secara tak langsung mengalami kekerasan verbal yang dilontarkan orang tuanya seperti membentak, menakuti, serta mengecam anak ketika pembelajaran daring. Ucapanucapan negatif yang dilontarkan orang tua kepada anaknya bisa membuat anak merekam hal tersebut dan tersimpan dalam memorinya. Banyak orang tua ketika masa pandemi saat ini membimbing anaknya dalam melakukan pembelajaran daring tak sadar marah jika anak belum bisa dan membuat anak menjadi ketakutan. Padahal, orang tua adalah tempat pertama anak bersosialisasi, bertumbuh, dan berkembang. Perkembangan sosial anak sangat dipengaruhi oleh bagaimana orang tua memperlakukannya dan menjadi role model kepada anak. 
Oleh karena itu, sudah menjadi keharusan orang tua memberikan contoh yang baik kepada anak serta memberikan menstimulasi anak dengan baik.

Pembatasan interaksi sosial selama pandemi telah membatasi ruang sosial anak-anak, dan mereka tidak dapat meninggalkan rumah dan bermain bebas dengan teman sebayanya. Pembatasan interaksi sosial anak akan memengaruhi perkembangan sosial anak. Perkembangan sosial adalah hasil dari hubungan sosial yang matang, juga dapat dipahami sebagai proses pembelajaran norma, etika dan tradisi, yaitu menyatukan diri menjadi satu kesatuan yang saling tukar menukar dan bekerjasama. Hal tersebut akan berdampak pada keadaan psikologis anak, membuatnya tidak terbiasa dengan lingkungan sosialnya di kemudian hari, serta tidak mau berinteraksi dengan orang lain.

Perkembangan sosial seorang anak akan mempengaruhi cara anak berinteraksi dengan lingkungan anak dan manfaat yang dapat diperolehnya dari interaksi tersebut. Jika anak berinteraksi dalam lingkungan yang negatif, maka perilakunya juga akan negatif, terutama siswa sekolah dasar dengan perkembangan sosial yang pesat. Oleh karena itu, orang tua dan guru perlu memperhatikan dan mengawasi agar anak tidak terpengaruh oleh kehidupan sosial yang negatif.

\section{SIMPULAN}

Pembelajaran daring di masa pandemi memberikan pengaruh terhadap perkembangan sosial anak jenjang sekolah dasar khususnya kelas 6 SD. Hasil dari penelitian ini memperlihatkan bahwa pembelajaran daring berpengaruh terhadap perkembangan sosial anak seperti anak menjadi kurang dalam bersosialisasi dengan teman sebaya dan juga lingkungan sekitarnya, rasa bosan dan jenuh yang diakibatkan karena kondisi lingkungan yang kurang menarik dan monoton, anak terkadang merasa rindu dengan guru juga teman-teman sekolahnya, serta terkadang anak mengalami kekerasan verbal yang dilakukan oleh lingkungan terdekatnya yaitu keluarga. Semoga hasil dari penelitian ini dapat menjadi referensi serta bahan pertimbangan untuk melakukan evaluasian terhadap pembelajaran daring yang jika dilihat akan terus berlanjut selama pandemi ini belum berakhir.

\section{DAFTAR PUSTAKA}

Dewi, M. P., Neviyarni, S., \& Irdamurni, I. (2020). Perkembangan Bahasa, Emosi, Dan Sosial Anak Usia Sekolah Dasar. Jurnal Ilmiah Pendidikan Dasar, 7(1), 1-11.

Dewi, W. A. F. (2020). Dampak Covid-19 terhadap implementasi pembelajaran daring di Sekolah Dasar. Edukatif: Jurnal Ilmu Pendidikan, 2(1), 55-61.

Ilham, I. (2020). Perkembangan Emosi Dan Sosial Pada Anak Usia Sekolah Dasar. eL-Muhbib: Jurnal Pemikiran dan Penelitian Pendidikan Dasar, 4(2), 162-180. 
Jati, L. T. S., \& Sumarni, W. (2020). Dampak Pandemi Covid-19 Terhadap Perkembangan Anak Sekolah Dasar. In Prosiding Seminar Nasional Pascasarjana (PROSNAMPAS) (Vol. 3, No. 1, pp. 776-783).

Kartika, E., \& Herawati, N. I. (2012). Karakteristik Perkembangan Sosial Emosi Siswa SD Laboratorium UPI Kampus Cibiru Dikaitkan Dengan Sistem Pembelajaran Full Day School. EduHumaniora| Jurnal Pendidikan Dasar Kampus Cibiru, 1(1).

Kusuma, W. S., \& Sutapa, P. (2020). Dampak Pembelajaran Daring terhadap Perilaku Sosial Emosional Anak. Jurnal Obsesi: Jurnal Pendidikan Anak Usia Dini, 5(2), 1635-1643.

Latifah, U. (2017). Aspek perkembangan pada anak Sekolah Dasar: Masalah dan perkembangannya. Academica: Journal of Multidisciplinary Studies, 1(2), 185-196.

Magdalena, I., Nokhriyana, A. D., Sipayung, K. N. S., \& Tsania, S. (2020). Dampak Covid-19 terhadap Implementasi Pembelajaran Daring di Sekolah Dasar. BINTANG, 2(3), 323-333.

Masrul, M., Tasnim, J. S., Daud Oris Krianto Sulaiman, C. P., Purnomo, A., Febrianty, D. H. S., Purba, D. W., \& Ramadhani, Y. R. (2020). Pandemik COVID-19: Persoalan dan Refleksi di Indonesia. Medan: Yayasan Kita Menulis.

Nandwijiwa, V., \& Aulia, P. (2020). Studi Deskriptif Peran Orang Tua terhadap Perkembangan Sosial Anak Usia Dini pada Masa Pandemi Covid19. Jurnal Pendidikan Tambusai, 4(3), 3145-3151.

Norkhalifah, S. (2021). Pengaruh Pembatasan Interaksi Sosial Di Masa Pandemi Covid-19 Pada Anak Usia Dini.

Rohayani, F. (2020). Menjawab Problematika yang Dihadapi Anak Usia Dini di Masa Pandemi Covid-19. Qawwam, 14(1), 29-50.

Sari, R. P., Tusyantari, N. B., \& Suswandari, M. (2021). Dampak Pembelajaran Daring Bagi Siswa Sekolah Dasar Selama COVID-19. Prima Magistra: Jurnal Ilmiah Kependidikan, 2(1), 9-15.

Suhada, I. (2017). Perkembangan Peserta Didik. Bandung: PT Remaja Rosdakarya.

Tusyana, E., \& Trengginas, R. (2019). Analisis Perkembangan Sosial-Emosional Tercapai Siswa Usia Dasar. Inventa: Jurnal Pendidikan Guru Sekolah Dasar, 3(1), 18-26. 